\title{
The Influence of the Level of Environmental Complexity and Turbulence on the Choice of Marketing
} Tactics

\author{
Roger B. Mason, Thomas Dobbelstein \\ Institute of Systems Science, Durban University of Technology, South Africa \\ Baden-Württemberg Cooperative State University, Ravensburg, Germany \\ rogerm@dut.ac.za
}

\begin{abstract}
This paper proposes that the choice of marketing tactics is influenced by the company's external environment. It aims to illustrate the marketing tactics suggested for a complex, turbulent environment, when marketing and the environment are viewed through a complexity lens. A quantitative, descriptive, cross sectional study was used, based on an e-mailed survey to a purchased mailing list, which resulted in a sample of 860 senior marketing or sales managers in medium to large profit oriented businesses in South Africa. The study found that the manager's evaluation of the environment as complex/turbulent was important, and that there is a relationship between the use of destabilizing marketing tactics and complex/turbulent environments. Although there is only a limited relationship with 'success', the study generally stresses the importance of destabilizing tactics, and in fact, all marketing tactics, in a complex/turbulent environment. Most work on complexity in marketing has concentrated on strategy, with little emphasis on tactics and the marketing mix. Therefore, this paper is an important contribution to the understanding of marketing mix choices, of interest to both practicing marketers and marketing academics.
\end{abstract}

Keywords: Complexity theory, chaos theory, external environment, marketing tactics, stabilizing, destabilizing

\section{Introduction}

With the demise of the Apartheid government, and the development of a new constitutional democracy, South Africa has seen dramatic changes in all aspects of the external environment over the past 25 years. Continual change and disruption in the politico-legal, economic, socio-cultural and technological environments have meant a more complex and dynamic environment resulting in continuous challenges for business management. It has been proposed that such levels of complexity and turbulence must influence the nature of marketing tactics adopted by firms operating in such environments. Most research in this field relates to traditional methods, such as planning, forecasting and scenario planning, which are inadequate to cope with the speed, volume and unpredictability of discontinuous change (Edgar and Nisbet, 1996; Leitner, 2015).Most of the research using the new sciences (chaos and complexity theory) which are more suited to the volatility of turbulent and complex environments(Smith, 2002; Wollin and Perry, 2004; Gundlach, 2006; Turner, 2014; Woodside, 2015) have been either theoretical (e.g. Smith, 2002; Wollin and Perry, 2004), based on simulations or statistics (e.g. Hibbert and Wilkinson, 1994;Vojtko and Heskova, 2010),or exploratory/qualitative studies (Mason, 2004, 2008, 2012, 2013a \& b; Mason and Staude, 2007, 2009).Thus a gap in the literature exists for a more quantitative approach to descriptive and/or conclusive research, adopting a new sciences approach.

Therefore, the purpose of this paper is to assess marketing activities (tactics) applied in complex and turbulent environments, as suggested by a review of the chaos and complexity literature, as applied to marketing. The following objectives were set to meet the above purpose:

- To test the model of the marketing mix tactics that could be expected to be found in successful companies in complex and turbulent environments,

- To identify the differences in marketing mix tactics between companies operating in complex/turbulent industries and in simple/stable industries,

- To identify the relationship between the different marketing mix tactics and marketing success in complex/turbulent industries. 
A quantitative survey was used, investigating South African firms' perceptions of their environments and their marketing tactics. Thus, this study used both the new sciences and an emerging market context to add to the marketing and complexity literature on the choice of marketing tactics for turbulent environments versus those used in stable environments.

\section{Literature Review}

Context of the study: The business environment is becoming extremely volatile and complex, experiencing continuous, rapid change (Doherty and Delener, 2001; Priyanker and Srinivasan, 2015), or, as Weeks (2014: 718) terms it, "black swan events and extreme uncertainty". In stable environments, coping is relatively easy, but as complexity increases, and change happens faster, coping becomes problematic. Traditional methods, such as planning, forecasting and scenario planning, have become inadequate to cope with the speed, volume and unpredictability of discontinuous change (Edgar and Nisbet, 1996; Leitner, 2015). Therefore, finding new ways of coping are essential (Fodness, 2015). One way of finding such new ways is by applying theories from outside marketing to obtain fresh insights. Many authors believe the new sciences, chaos and complexity theories, provide a set of powerful, intellectual tools (Turner, 2014: 7) that can provide a better understanding of marketing (Smith, 2002; Gundlach, 2006; Woodside, 2015). Wollin and Perry (2004: 569) maintain that:

"...Complexity theory...has implications for marketing managers as a holistic, self-consistent framework for understanding profound forces within a market and provides some guides for action when operating within such a system."

Another method of finding new ways is to use emerging markets as laboratories to expand marketing knowledge, as these markets are significantly different to those in industrialized countries (Burgess and Steenkamp, 2006). Theories and assumptions can be tested in contexts different to those in which the traditional marketing theories were developed. South Africa is an emerging market, different to the western markets in which most marketing theory was developed, and as such makes a good 'laboratory' for testing new marketing ideas.

Business environment: The business environment is comprised of relationships between environmental stakeholders, which 'co-create' the fast changing environment (Conner, 1998). Change occurs in two major dimensions; complexity and turbulence. As complexity increases, the ability to understand, plan and predict becomes more difficult (Black and Farias, 2000). The increasing complexity leads to more change (Conner, 1998) and uncertainty (Ashill and Jobber, 2013), and making sense of it and predicting its behavior becomes more difficult (Black and Farias, 2000). Shalender and Singh (2015) maintain that today's environment is in a "chronic state of flux" and Wilden and Gudergan (2015: 181) maintain that how "Marketing...align(s) with changing environments to secure superior performance remains unclear." Turbulence involves rapid, unexpected change in the environmental sub-dimensions (Conner, 1998). It is caused by changes in, and interaction between, environmental factors, including technology and the confluence of the computer, media and telecommunications industries. This turbulence results in less orderly competition, increasing need for information, quicker development cycles and more difficulty in predicting customer, product and service requirements (Chakravarthy, 1997). The net result of these changes is an environment with strong Knightian uncertainty, which states that the future is unknowable (Wilkinson and Young, 2005).

Many authors see such complex, turbulent environments as complex adaptive systems (CASs) (Holbrook, 2003). Others highlight the presence of complexity and chaos constructs in business environments, such as eco-systems (Ritter et al., 2004; Gundlach, 2006), self-organization and emergence (Wilkinson, 2006), sensitive dependence on initial conditions (Tedesco Analytics, 2001) and non-linearity (Black and Farias, 2000; Tedesco Analytics, 2001: 3). Furthermore, Black and Farias (2000) explain how actions taken to reduce uncertainty can lead to non-linearity and unpredictability, causing the marketplace to be in a continuous state of disequilibrium. Since environments do appear to be CASs, a complexity or chaos perspective should be used to understand their dynamics and behavior and to guide strategy development (Tedesco Analytics, 2001; Mason, 2007). For example, an entrepreneurial approach of constructing the future, rather than trying to predict the future, can be helpful (Mason, 2006). This literature has shown that the business environment can be seen as a complex adaptive system and that therefore alternative methods are required to manage 
marketing activities, especially when the system heads towards volatility with increasing complexity and turbulence, as exists in the South African market. This justifies the need to view the research problem with a complexity lens.

Complexity theory: Complexity theory is an overarching theory that includes a number of other theories, such as chaos theory, autopoiesis, dissipative structures, catastrophe theory and fractal geometry. A detailed explanation of the complexity theory is not possible in this paper, but a short discussion on the key components is given below. The underlying idea of complexity 'is that all things tend to self-organise into systems' when simple rules are applied (Kelly \& Allison, 1999). These systems can produce unexpected patterns or behaviours (Goldberg \& Markoczy, 1998; Manuj \& Sahin, 2011) because of non-linear feedback networks (Stacey, 1996), the interconnection and interdependence of complex systems (Bar-Yam, 2000) and because the system's parts interact and adapt to each other (Meade \& Rabelo, 2004). Complex behaviour is orderly, yet full of surprise; it is apparently uncontrollable, yet not totally chaotic. The rules that generate this behaviour are not enforced by a 'manager', and cannot be predicted from any single part of the system and thus cannot be controlled (Wu \& Zhang, 2007). Several complexity concepts have relevance to business.

The central concept is self-organisation; the process of order emerging from simple rules in a system, which a 'manager' does not control (Holbrook, 2003), but which is due to the interaction between autonomous actors or agents in the system (Wilkinson \& Young, 2013; Arévalo and Espinoza, 2014). Creative and innovative responses emerge despite the difficulty of 'managing' the system (Dolan, Garcia \& Auerbach, 2003). This emergence, the second important concept, happens when the system changes, leading to disorder and prevention of the systemfrom ossifying. Emergence happens at the edge-of-chaos, enabling new actions to emerge. This spontaneous organization creates new types of order (Turner, 2014). For example, new product development behavior emerges from the operational level (McCarthy et al., 2006). The third concept is feedback. Negative feedback damps change, pushing systems to equilibrium (Stacey, 1995). Positive feedback amplifies small changes, pushing systems towards chaos (Doherty \& Delener, 2001). Together, positive and negative feedback balance the system at the 'edge-of-chaos', which is the best position for turbulent environments (Doherty \& Delener, 2001). Tarokh, Dabiri, Shokouhi and Shafiei (2011) showed how inventory management can produce self-reinforcing positive or negative feedback loops.

The fourth concept is sensitive dependence on initial conditions (Briggs \& Peat, 1999). In stable systems, small changes have small effects, but in complex or turbulent systems small changes can grow exponentially, making long-term prediction impossible (Doherty \& Delener, 2001; Holbrook, 2003; Wu \& Zhang, 2007). This phenomenon, also known as the 'butterfly effect', is similar to the 'bullwhip effect' in supply chains (BadilloPina, Tejeida-Padilla \& Morales- Matamoros, 2012), which is typical of over-or under-reacting in dynamic environments (Wilkinson \& Young, 2013). Small nudges, at the correct time, can lead to major changes (Wheatley, 1996). Patterns and clues indicate which changes to 'nudge' (Morrison \& Quella, 1999) and when to nudge them (Gladwell, 2000). These patterns are known as attractors, which is the fifth concept. The edgeof-chaos attractor, known as a 'strange attractor', reflects the area where maximum creativity and innovation happens (Lewin, 1992). A unique feature of the strange attractor is that it stays within certain boundaries (Holbrook, 2003). How the system will develop cannot be predicted, but it will not go outside its attractor (Doherty \& Delener, 2001). Thus, the attractor allows change whilst maintaining some order. These basic characteristics of complexity theory require different types of marketing reactions when an environment increases in complexity and turbulence. These complexity marketing approaches will be explicated, but first it is necessary to define what the standard, or traditional, marketing actions involve.

Traditional Marketing Approaches: Marketing success in a turbulent environment requires an approach that is different to that recommended by traditional strategic marketing theory. For example, the Product Life Cycle approach can be misleading if other environmental factors are not considered concurrently, and the marketing warfare approach focuses only on the competitive environment. Thus, such strategic approaches are unlikely to enable companies to develop and maintain defendable, competitive positions over the long term. Furthermore, they are not consistent with the current strategic approaches of collaboration and networking (Mason, 2004). Other authors who believe that sequential strategic marketing planning is too slow and unresponsive for a fast changing marketplace support this criticism of the traditional approach to marketing strategy. Nor can traditional marketing planning keep up with customers' requirements or 
aggressive competitors (Nilson, 1995; Heilbrunn, 1995). In addition, traditional market research and traditional marketing mix models are too simplistic to understand complex marketing situations as such models assume linear relationships between mix variables and outcomes (Tedesco, 1998). In addition, Shalender and Singh (2015) see traditional approaches as irrelevant because of the lack of stability in environments. They produce strategies that follow rather than anticipate market changes (Singer, 2006). Since the simplistic approaches recommended by traditional theories can be dangerous, marketers should consider non-traditional marketing methodologies (Wollin and Perry, 2004). Such alternative marketing approaches have been termed 'complexity marketing' and are now explained.

Complexity Marketing Approaches: In complex and turbulent environments, speed in recognizing opportunities and developing new products, and reducing time to market is essential (Seybold, 2000). For marketing to be effective it must be proactive, creating events, and not merely relying on market research, as competitors can too easily copy the reactive following of customer requests. In other words, marketing flexibility and innovation is essential (Shalender and Singh, 2015). Richardson (1996) supports this view by maintaining that traditional marketing is inadequate for the future complex modern economy, while Vojtko and Heskova (2010) stress the importance of systems dynamics and thinking and agent-based modeling in such environments.

As the environment, product and customers become more complex, the firm must focus its scarce resources on those activities that will give the best result (Nilson, 1995). For example, Weeks (2014) stresses the importance of resilience (anticipating and adjusting to environmental trends), while Liu et al. (2015) found that corporate performance is related to how well the firm reacts to environmental complexity. There are two approaches to using marketing tactics effectively in complex and turbulent environments: stabilizing or destabilizing approaches (Nilson, 1995; McGlone and Ramsey, 1998; Melton and Hartline, 2015). Theodiridis (2009) suggests a similar approach of either absorbing, or adapting to, complexity. Stabilizing activities encourage the system to stay within boundaries, while destabilizing activities cause unanticipated consequences that break the system boundaries. This is typical of a 'chaos system'. A system operating at the edge of chaos is preferred because stabilizing and destabilizing activities can be used to balance the system between uncontrollability and stagnation. Thomas (in D'Aveni, 1999: 129) found that destabilizing tactics used in turbulent markets lead to greater success than when stabilizing tactics are used in such markets. To avoid lock-in to old or obsolete technologies or products, and hindering new product development, Mohr (2001: 45) suggests 'creative destruction', which involves continuous innovation to make the firm's own products obsolete and to replace them with the firm's own new developments.

Table 1: Nature of marketing tactics

\begin{tabular}{|c|c|c|c|}
\hline \multicolumn{3}{|c|}{ Stabilizing/destabilizing nature } & $\begin{array}{l}\text { Perceived importance of tactics by } \\
\text { successful firm in turbulent environment }\end{array}$ \\
\hline & $\begin{array}{l}\text { Most destabilizing } \\
\text { Totally new products } \\
\text { Price change } \\
\text { Product innovation } \\
\text { development) } \\
\text { Sales promotion } \\
\text { Product enhancement } \\
\text { development) } \\
\text { PR \& other non-advertising } \\
\text { Advertising } \\
\text { Personal selling }\end{array}$ & $\begin{array}{l}\text { (new product } \\
\text { (old product } \\
\text { communication }\end{array}$ & \begin{tabular}{|l} 
Most important \\
Personal selling \\
Product innovation \\
Develop new products \\
PR/other communications \\
Product enhancement \\
Media advertising \\
Price changing \\
Sales promotions \\
Distribution \\
Least important
\end{tabular} \\
\hline
\end{tabular}

Own distribution system

Most stabilizing

Source: Nilson, 1995

Source: Mason, 2004, 2009

From a chaos and complexity perspective, stabilizing is reducing change by encouraging negative feedback, or damping, which brings the system back towards its equilibrium point, or to within its attractor boundaries 
(Nilson, 1995; Hibbert and Wilkinson, 1994). In a marketing sense, Nilson (1995: 47) says that destabilizing means the disrupting of a 'stable' environment, increasing the rate of change, setting off events to change the market or unsettling the established market. Destabilization can be seen as encouraging positive feedback ('the nudge' effect), which moves the system away from the status quo. Thus, destabilization can be either small, seemingly insignificant actions that influence the environment, or large dramatic actions that cause dramatic shifts in the environment. However, it must be remembered that, although the outcome is uncertain, such risk-taking leads to greater marketing competencies and innovation in turbulent environments, especially when related to product or service development (Garcia, 2004; Melton and Hartline, 2015). Further, Droge et al. (2009) showed that innovativeness is linked to new product success in turbulent markets. The literature on 'complexity marketing' has shown that it is not enough to view marketing tactics in terms of the standard 4Ps, but it is also necessary to understand whether each tactic 'stabilizes' or 'destabilizes' the environment. For example, strengthens of weakens a relationship with customers, or encourages or discourages brand switching, some of the findings from the literature in terms of stabilizing and destabilizing marketing tactics are shown in Table 1.

Research into marketing tactics: Although literature searches show that considerable work, from a complexity viewpoint, has been done on management, strategy and networks, very little has been done on marketing in general, and especially on marketing tactics. What have been done have been exploratory, conceptual, simulations, or using test or generated data. Almost nothing has been done on studying companies' actual marketing from a non-linear approach (Ritter et al., 2004). A considerable body of exploratory work has since been developed by Mason $(2004,2008,2012,2013$ a \& b) and Mason and Staude $(2007,2009)$, but there is still a lack of conclusive, larger sample, empirical work in this field. South Africa has a very complex and turbulent business environment, yet businesses tend to make no allowances in their marketing planning for whether their environment is complex/turbulent or simple/stable. No quantitative research into this situation has been done locally, and very little internationally. Thus, marketers lack guidance on how marketing tactics should differ according to the nature of the environment, and thus may be adopting inappropriate marketing tactics. This can result in waste of scarce resources and lack of competitiveness against foreign competition in the local market, and unsuccessful marketing in export markets. Therefore, a conclusive, cross-sectional study with a larger sample, based on the findings of this exploratory work, was developed. The aim of the study was thus to assess the findings from the exploratory research and to see if they could be supported when examined via a larger sample across a wide variety of industries. To support this aim, the following research questions were set:

\section{Research questions}

RQ 1: Do companies in a more complex/turbulent environment feel that more destabilizing marketing tactics are more important?

RQ 2: Do companies in a more simple/stable environment feel that more stabilizing marketing tactics are more important?

Research objectives: To answer the research questions, the following objectives were set:

- to test the model of the marketing mix tactics that could be expected to be found in successful companies in complex and turbulent environments,

- to identify the differences in marketing mix tactics between companies operating in complex/turbulent industries and in simple/stable industries,

- To identify the relationship between the different marketing mix tactics and marketing success in complex/turbulent industries.

Research variables: Based on the literature and the research objectives, the variables for the study are:

Dependent variable: More or less success, measured by the respondents' assessment of their operating profit being above or below the industry average 


\section{Independent variables:}

a. Complex/turbulent environment or simple/stable environment, measured via a number of questions about the nature of the respondents' environments

b. Stabilising or destabilising marketing mix tactics adopted, measured via a number of questions about the importance of various tactics in their marketing activities

\section{Methodology}

To achieve the objectives, the following methodology was used:

Research design: A quantitative, descriptive, cross sectional e-mailed survey to a purchased mailing list was used.

Respondents: The population was comprised of senior marketing or sales managers in all medium to large profit oriented businesses in South Africa. From this population, a list of 8093 businesses meeting the above criteria was purchased and a questionnaire e-mailed to the whole list. This was an opt-in list with all the list members having indicated a willingness to receive mailings. Since this was essentially a self-selected sample (i.e. list members chose whether to respond or not) the sampling method was non-probability. In this research, opinions are measured on a 5-point Likert scale. Assigning the accepted error at 0,1 and the significance level at $95 \%$, and estimating a standard deviation of 1, a sample size of 384 is necessary. It is intended to compare two different groups (mainly high and low complexity/turbulence). Assuming that the two compared groups have the same size, an overall sample size of $2 * 384=768$ is necessary. . Of the 8093 questionnaires mailed out, $0,94 \%$ were rejected/not delivered, leaving a net population of 8017 . Of these, 860 useable responses were returned, giving a response rate of $10,73 \%$. The sample size provided a cushion in case the compared groups did not have the same size. Therefore we conclude that the sample was adequate and probably acceptably representative of the target population.

Data collection: A questionnaire based on relevant literature, including the previously mentioned qualitative study, was developed and distributed via e-mail to a purchased address list. The only demographic type question asked what industry the company operating in. The list of industries was based on the industries as specified by the McGregor BFA (2012) database, A letter of information and consent was built into the opening pages of the questionnaire confirming that the respondent had fully understood their rights and agreed to participate in the study. Thus, the questionnaire was an opt-in survey. Confidentiality and anonymity was ensured by the questionnaire not asking for any individual or business names..

Data analysis: The independent variables were created and measured as follows. Based on the eight turbulence and complexity questions used as indicators, indices of turbulence and complexity were created, to be able to rank the industries in terms of complexity and turbulence. The questions relating to marketing activities were grouped according to the standard four marketing mix factors (product, price, place and promotion) and were also grouped into stabilizing and destabilizing factors as per Nilson (1995), Mason (2004) and Mason and Staude (2009). The dependent variable, 'more or less success', was identified by asking respondents to indicate whether their firm's average operating profit was higher or lower than the average that had been calculated by McGregor BFA (2012). Note that for banks and financial services, operating profit is meaningless, and so average return on assets was used to identify successful or less successful performance. Using these variables, the research questions described above were assessed.

Validity and reliability: Face validity and construct validity were achieved by a comprehensive review, deconstruction, and analysis of, and detailed discussion of, the questionnaire, the individual questions, and their response categories. Individual questions were carefully matched to the dependent and independent variables to ensure that the questionnaire assessed what we intended it to assess. Furthermore, a pilot test of the questionnaire was conducted with twenty business marketers who matched the population criteria -. To assess reliability, Cronbach's Coefficient Alpha was used..The values of 0,59 for turbulence and 0,63 for complexity are just enough to be acceptable. 


\section{Findings}

The 860 respondents were made up of membership of the various industries as shown in Table 2. The average operating profit margins for 2011 for each industry taken from the McGregor BFA (2012) database are also shown in Table 2.

Table 2: Sample

\begin{tabular}{llll}
\hline Industry & N & \% & $\begin{array}{l}\text { Average operating } \\
\text { profit margin }\end{array}$ \\
\hline Information technology & 92 & 10.7 & 4.44 \\
Business support services and training & 89 & 10.3 & 5.93 \\
Health care & 69 & 8.0 & 21.61 \\
*Financial services & 62 & 7.2 & $0.24{ }^{*}$ \\
Building, construction and materials & 54 & 6.3 & 4.98 \\
Travel and leisure & 53 & 6.2 & 23.76 \\
Retail & 46 & 5.3 & 6.48 \\
Food & 45 & 5.2 & 11.36 \\
Telecommunications & 38 & 4.4 & 26.65 \\
Automobiles. Parts and tyres & 36 & 4.2 & 11.04 \\
Electronics and electrical & 33 & 3.8 & 9.86 \\
Transport & 32 & 3.7 & 5.84 \\
Media & 31 & 3.6 & 21.85 \\
Beverages & 29 & 3.4 & 23.95 \\
Chemicals & 28 & 3.3 & 9.95 \\
Other & 27 & 3.1 & -- \\
Insurance & 23 & 2.7 & 27.08 \\
*Banks & 22 & 2.6 & $4.3 *$ \\
Clothing, footwear, leisure and personal products & 19 & 2.2 & 20.38 \\
Household goods and house construction & 17 & 2.0 & 5.93 \\
Packaging & 15 & 1.7 & 9.41 \\
TOTAL & 860 & 100.0 & \\
\hline
\end{tabular}

* For Banks and Financial services $=$ Average return on assets

Responses related to independent variables: To identify the first independent variable, namely perceived levels of turbulence and complexity in each industry, the questionnaire included four questions each. These questions and the descriptive answers are provided in Table 3.

Table 3: Perceived levels of turbulence and complexity questions

\begin{tabular}{|c|c|c|c|c|c|}
\hline Questions & $\mathbf{N}$ & Min & Max & Mean & $\begin{array}{l}\text { Std } \\
\text { Dev }\end{array}$ \\
\hline $\begin{array}{l}\text { We are continuously having to react to changes in our external } \\
\text { environment and to aggressive competitive activities }\end{array}$ & 851 & 1 & 5 & 4.05 & 0.977 \\
\hline $\begin{array}{l}\text { The number of issues that influence our industry simultaneously is not } \\
\text { very high }\end{array}$ & 849 & 1 & 5 & 3.87 & 0.986 \\
\hline Change is very high in our industry and happens very rapidly & 855 & 1 & 5 & 3.63 & 1.143 \\
\hline $\begin{array}{l}\text { My company collaborates with suppliers, competitors and/or other } \\
\text { companies in our industry in marketing our products or services. }\end{array}$ & 850 & 1 & 5 & 3.38 & 1.352 \\
\hline The future in our industry is quite easy to predict & 852 & 1 & 5 & 3.27 & 1.112 \\
\hline $\begin{array}{l}\text { Recoded: The events in our business environment are mostly familiar. } \\
\text { In other words, we do not experience a lot of new, unfamiliar or } \\
\text { unexpected happenings }\end{array}$ & 852 & 1 & 5 & 3.05 & 1.133 \\
\hline $\begin{array}{l}\text { The outcome of marketing actions in our industry is uncertain, } \\
\text { surprises are common }\end{array}$ & 854 & 1 & 5 & 2.98 & 1.057 \\
\hline $\begin{array}{l}\text { Original: The events in our business environment are mostly familiar. } \\
\text { In other words, we do not experience a lot of new, unfamiliar or }\end{array}$ & 852 & 1 & 5 & 2.95 & 1.133 \\
\hline
\end{tabular}


unexpected happenings

The relationship between cause and effect in our industry is rather $\begin{array}{llllll}850 & 1 & 5 & 2.95 & 1.084\end{array}$ unpredictable. In other words it is difficult to be sure of the effect of any activities that we undertake

The questions identifying the second independent variable, the perceived importance of the various marketing activities to the company, are provided in Table 4, together with their descriptive answers.

Table 4: Perceived importance of various marketing activities

\begin{tabular}{|c|c|c|c|c|c|}
\hline Questions & $\mathbf{N}$ & Min & Max & Mean & Std Dev \\
\hline Personal selling aimed at retaining customers (relationship selling) & 852 & 1 & 5 & 4.41 & 0.894 \\
\hline $\begin{array}{llll}\begin{array}{l}\text { Product/service } \\
\text { products/services) }\end{array} & \text { enhancement } & \text { (improving } & \text { existing/old }\end{array}$ & 854 & 1 & 5 & 4.33 & 0.788 \\
\hline $\begin{array}{l}\text { Personal selling aimed at winning new customers away from } \\
\text { competitors }\end{array}$ & 851 & 1 & 5 & 4.11 & 0.998 \\
\hline Advertising aimed at building brand loyalty and image & 854 & 1 & 5 & 4.06 & 1.032 \\
\hline Developing totally new products or services & 850 & 1 & 5 & 4.03 & 1.002 \\
\hline Public relations \& other forms of non-advertising communications & 853 & 1 & 5 & 3.97 & 0.953 \\
\hline $\begin{array}{l}\text { Product/service innovation (new to company, but not new to } \\
\text { market) }\end{array}$ & 846 & 1 & 5 & 3.96 & 0.981 \\
\hline Having control over the distribution chain & 853 & 1 & 5 & 3.91 & 1.143 \\
\hline Sales promotions (non-price related) & 852 & 1 & 5 & 3.52 & 1.179 \\
\hline Price promotions, i.e. pricing included as part of a sales promotion & 851 & 1 & 5 & 3.31 & 1.311 \\
\hline Carrying buffer or safety inventory & 850 & 1 & 5 & 3.30 & 1.366 \\
\hline Using price cutting and discounting as a marketing weapon & 851 & 1 & 5 & 2.91 & 1.239 \\
\hline
\end{tabular}

Based on the perceived levels of turbulence and complexity, the various industries were plotted graphically on Figure 1. The circles indicate the six industries grouped as highly complex and turbulent, and the six grouped as low in complexity and turbulence.

Figure 1: Illustration of relative turbulence/complexity of industries

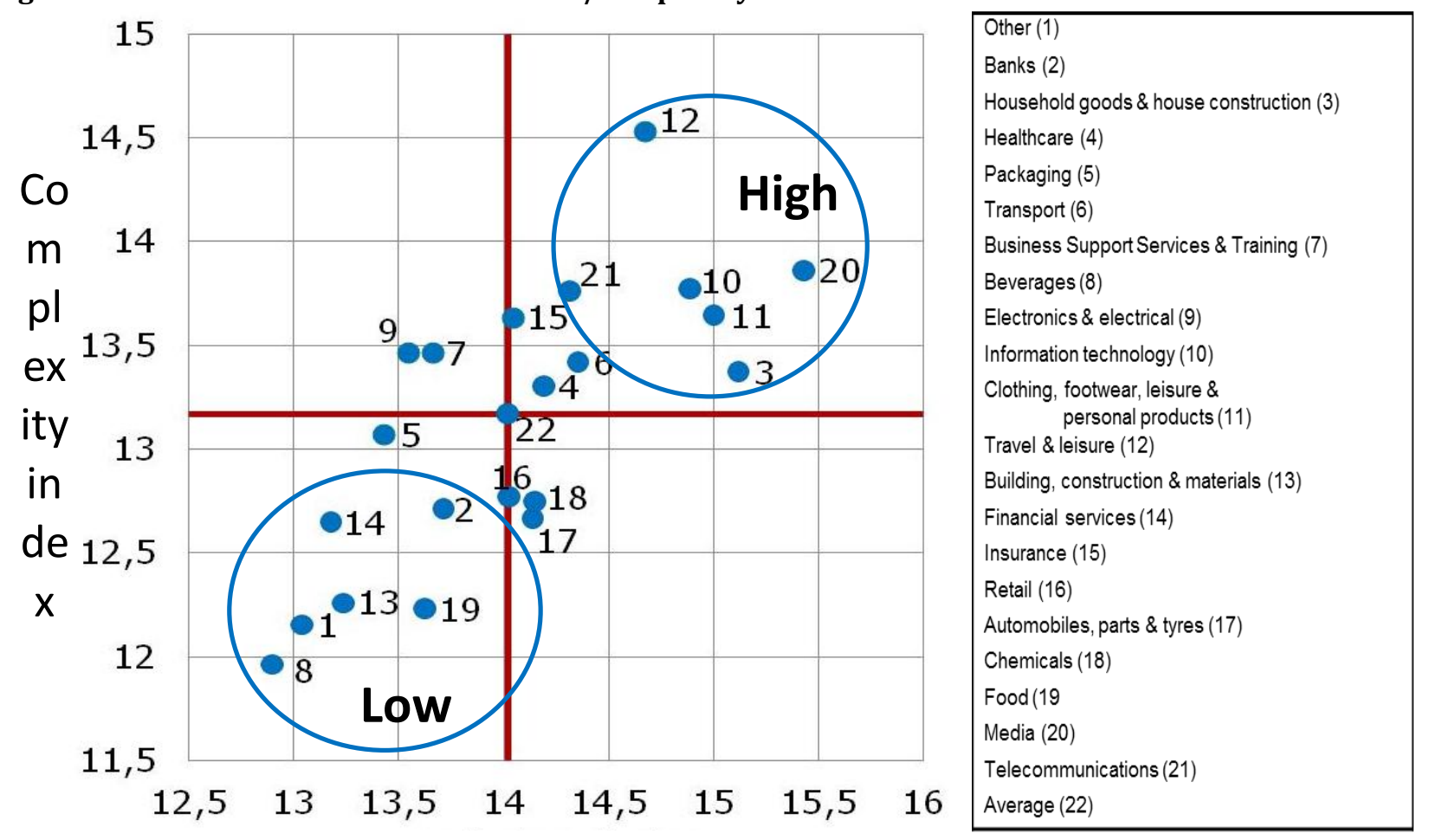

\section{Turbulence index}


Table 5: Perceived importance of marketing tactics by industry

\begin{tabular}{|c|c|c|c|c|c|c|c|c|c|c|}
\hline \multirow{2}{*}{\multicolumn{2}{|c|}{$\begin{array}{l}\text { Which industry describes } \\
\text { most closely the industry } \\
\text { that you operate in? }\end{array}$}} & \multicolumn{3}{|c|}{ Index (4 = low, 20 = high) } & \multicolumn{6}{|c|}{ Importance (1 = low, 5 = high $)$} \\
\hline & & \multirow[t]{2}{*}{$\begin{array}{l}\text { Turbu } \\
\text {-lence } \\
\text { index }\end{array}$} & \multirow{2}{*}{$\begin{array}{l}\text { Compl } \\
\text {-exity } \\
\text { index }\end{array}$} & \multirow[t]{2}{*}{$\begin{array}{l}\text { Mean of } \\
\text { Turb\&C } \\
\text { ompl }\end{array}$} & \multirow[t]{2}{*}{$\begin{array}{l}\text { Pro- } \\
\text { duct }\end{array}$} & \multirow[t]{2}{*}{$\begin{array}{l}\text { Place } \\
3.63\end{array}$} & \multirow{2}{*}{$\begin{array}{l}\text { Price } \\
2.85\end{array}$} & \multirow{2}{*}{$\begin{array}{l}\text { Prom- } \\
\text { otion }\end{array}$} & \multirow{2}{*}{$\begin{array}{l}\text { Mean } \\
\text { Destabili- } \\
\text { zing tactics }\end{array}$} & \multirow{2}{*}{$\begin{array}{l}\text { Mean } \\
\text { stabilizing } \\
\text { tactics }\end{array}$} \\
\hline Other & Mean & & & & & & & & & \\
\hline & $\mathrm{N}$ & 27 & 26 & 27 & 27 & 27 & 26 & 27 & 27 & 27 \\
\hline \multirow[t]{2}{*}{ Banks } & Mean & 13.71 & 12.71 & 13.11 & 4.08 & 3.07 & 2.66 & 4.07 & 3.42 & 3.91 \\
\hline & $\mathrm{N}$ & 21 & 21 & 22 & 22 & 22 & 22 & 22 & 22 & 22 \\
\hline Household goods \& & Mean & 15.12 & 13.38 & 14.18 & 4.33 & 4.12 & 3.68 & 3.95 & 3.88 & 4.18 \\
\hline house construct & $\mathrm{N}$ & 17 & 16 & 17 & 17 & 17 & 17 & 17 & 17 & 17 \\
\hline \multirow[t]{2}{*}{ Health care } & Mean & 14.19 & 13.30 & 13.75 & 4.17 & 4.00 & 2.83 & 4.00 & 3.66 & 4.03 \\
\hline & $\mathrm{N}$ & 68 & 69 & 69 & 69 & 69 & 69 & 69 & 69 & 69 \\
\hline \multirow[t]{2}{*}{ Packaging } & Mean & 13.43 & 13.07 & 13.25 & 3.73 & 4.07 & 3.37 & 3.96 & 3.66 & 3.99 \\
\hline & $\mathrm{N}$ & 14 & 14 & 14 & 15 & 15 & 15 & 15 & 15 & 15 \\
\hline \multirow[t]{2}{*}{ Transport } & Mean & 14.35 & 13.42 & 13.89 & 3.99 & 3.61 & 2.73 & 3.81 & 3.38 & 3.89 \\
\hline & $\mathrm{N}$ & 31 & 31 & 31 & 31 & 31 & 31 & 31 & 31 & 31 \\
\hline Business support & Mean & 13.66 & 13.47 & 13.54 & 4.08 & 3.00 & 2.89 & 3.95 & 3.47 & 3.83 \\
\hline services \& training & $\mathrm{N}$ & 86 & 86 & 89 & 89 & 89 & 89 & 89 & 89 & 89 \\
\hline \multirow[t]{2}{*}{ Beverages } & Mean & 12.9 & 11.96 & 12.50 & 4.06 & 4.19 & 3.74 & 4.19 & 3.94 & 4.22 \\
\hline & $\mathrm{N}$ & 29 & 28 & 29 & 29 & 29 & 29 & 29 & 29 & 29 \\
\hline \multirow{2}{*}{$\begin{array}{l}\text { Electronics } \\
\text { electrical }\end{array}$} & Mean & 13.55 & 13.47 & 13.50 & 4.08 & 3.97 & 2.89 & 4.01 & 3.59 & 4.09 \\
\hline & $\mathrm{N}$ & 33 & 32 & 33 & 33 & 33 & 33 & 33 & 33 & 33 \\
\hline $\begin{array}{l}\text { Information } \\
\text { technology }\end{array}$ & Mean & 14.89 & 13.77 & 14.33 & 4.14 & 3.24 & 3.02 & 4.04 & 3.65 & 3.87 \\
\hline technology & $\mathrm{N}$ & 89 & 88 & 90 & 91 & 91 & 91 & 91 & 91 & 91 \\
\hline Clothing, footwear, & Mean & 15.00 & 13.65 & 14.39 & 4.20 & 4.19 & 3.83 & 4.20 & 4.06 & 4.22 \\
\hline $\begin{array}{l}\text { leisure \& personal } \\
\text { products }\end{array}$ & $\mathrm{N}$ & 18 & 17 & 18 & 18 & 18 & 18 & 18 & 18 & 18 \\
\hline Travel and leisure & Mean & 14.67 & 14.53 & 14.60 & 4.00 & 3.15 & 3.43 & 4.25 & 3.74 & 4.01 \\
\hline & $\mathrm{N}$ & 52 & 51 & 52 & 53 & 53 & 53 & 53 & 53 & 53 \\
\hline Building, & Mean & 13.24 & 12.26 & 12.75 & 3.99 & 3.83 & 2.84 & 3.92 & 3.44 & 4.05 \\
\hline $\begin{array}{l}\text { construction\& } \\
\text { materials }\end{array}$ & $\mathrm{N}$ & 51 & 54 & 54 & 54 & 54 & 54 & 54 & 54 & 54 \\
\hline Financial services & Mean & 13.18 & 12.65 & 12.96 & 4.11 & 3.01 & 2.49 & 3.96 & 3.34 & 3.84 \\
\hline & $\mathrm{N}$ & 62 & 60 & 62 & 62 & 62 & 62 & 62 & 62 & 62 \\
\hline Insurance & Mean & 14.04 & 13.64 & 13.87 & 4.23 & 3.33 & 3.15 & 4.12 & 3.70 & 4.01 \\
\hline & $\mathrm{N}$ & 23 & 22 & 23 & 23 & 23 & 23 & 23 & 23 & 23 \\
\hline Retail & Mean & 14.02 & 12.77 & 13.43 & 4.09 & 4.06 & 3.58 & 4.07 & 3.82 & 4.16 \\
\hline & $\mathrm{N}$ & 44 & 44 & 46 & 45 & 45 & 45 & 45 & 45 & 45 \\
\hline Automobiles. & Mean & 14.14 & 12.67 & 13.40 & 4.31 & 3.94 & 3.32 & 3.91 & 3.79 & 4.05 \\
\hline \& tyres & $\mathrm{N}$ & 36 & 36 & 36 & 36 & 36 & 36 & 36 & 36 & 36 \\
\hline Chemicals & Mean & 14.15 & 12.75 & 13.36 & 3.92 & 4.16 & 3.05 & 3.90 & 3.53 & 4.08 \\
\hline & $\mathrm{N}$ & 27 & 28 & 28 & 28 & 28 & 28 & 28 & 28 & 28 \\
\hline Food & Mean & 13.62 & 12.23 & 12.99 & 4.21 & 4.07 & 3.44 & 4.01 & 3.83 & 4.13 \\
\hline & $\mathrm{N}$ & 45 & 43 & 45 & 45 & 45 & 45 & 45 & 45 & 45 \\
\hline Media & Mean & 15.43 & 13.86 & 14.74 & 4.13 & 3.50 & 3.37 & 4.09 & 3.74 & 4.04 \\
\hline & $\mathrm{N}$ & 28 & 29 & 31 & 31 & 31 & 31 & 31 & 31 & 31 \\
\hline Telecommunications & Mean & 14.32 & 13.76 & 14.04 & 4.29 & 3.68 & 3.64 & 4.02 & 3.98 & 3.96 \\
\hline & $\mathrm{N}$ & 38 & 38 & 38 & 38 & 38 & 38 & 38 & 38 & 38 \\
\hline TOTAL & Mean & 14.02 & 13.17 & 13.60 & 4.10 & 3.60 & 3.11 & 4.01 & 3.64 & 3.99 \\
\hline & $\mathrm{N}$ & 839 & 833 & 854 & 856 & 856 & 855 & 856 & 856 & 856 \\
\hline
\end{tabular}

Table 5 provides the results by industry, of the perceived importance of the various marketing activities, grouped into the standard four marketing mix factors, and grouped according to whether they are stabilizing or destabilizing. Table 6 compares the importance of these same groupings of marketing activities according to those firms that perceived themselves as having above average profit margins versus those that perceived themselves as having below average profit margins. 
Table 6: Importance of marketing tactics according to relative profitability

\begin{tabular}{|c|c|c|c|c|c|c|c|c|c|c|}
\hline \multirow{2}{*}{\multicolumn{2}{|c|}{\begin{tabular}{lrr} 
Was & \multicolumn{2}{c}{ company's } \\
operating & profit \\
margin (OP) or \\
return on assets \\
(ROA)..........
\end{tabular}}} & \multicolumn{3}{|c|}{$4=$ low, 20 =high } & \multicolumn{6}{|c|}{ Importance (1 = low, 5 = high) } \\
\hline & & $\begin{array}{l}\text { Turbu } \\
\text {-lence } \\
\text { index }\end{array}$ & $\begin{array}{l}\text { Compl } \\
\text {-exity } \\
\text { index }\end{array}$ & $\begin{array}{l}\text { Mean } \\
\text { of } \\
\text { Turb\& } \\
\text { Compl }\end{array}$ & $\begin{array}{l}\text { Pro- } \\
\text { duct }\end{array}$ & $\begin{array}{l}\text { Plac } \\
\text { e }\end{array}$ & Price & $\begin{array}{l}\text { Prom- } \\
\text { otion }\end{array}$ & $\begin{array}{l}\text { Mean DE- } \\
\text { stabilizin } \\
\text { g tactics }\end{array}$ & $\begin{array}{l}\text { Mean } \\
\text { stabilizin } \\
\text { g tactics }\end{array}$ \\
\hline .....higher & Mean & 13.79 & 13.12 & 13.466 & 4.11 & 3.62 & 3.05 & 4.03 & 3.63 & 4.01 \\
\hline $\begin{array}{l}\text { than } \\
\text { aveOP/ROA? }\end{array}$ & $\mathrm{N}$ & 547 & 545 & 559 & 558 & 558 & 557 & 558 & 558 & 558 \\
\hline .....lower than & Mean & 14.44 & 13.26 & 13.866 & 4.08 & 3.58 & 3.22 & 3.98 & 3.66 & 3.96 \\
\hline aveOP/ROA? & $\mathrm{N}$ & 292 & 288 & 295 & 298 & 298 & 298 & 298 & 298 & 298 \\
\hline TOTAL & Mean & 14.028 & 13.17 & 13.604 & 4.10 & 3.60 & 3.11 & 4.01 & 3.64 & 3.99 \\
\hline & $\mathrm{N}$ & 39 & 833 & 854 & 856 & 856 & 855 & 856 & 856 & 856 \\
\hline
\end{tabular}

$\mathrm{OP}=$ Operating profit; ROA $=$ Return on assets

Reponses relating to the dependent variable: Table 7 indicates the proportion of companies in each industry that saw themselves performing either above or below the industry average operating profit, as identified by McGregor BFA (2012).

Table 7: Proportion of companies above/below average Profit/Return on Assets

\begin{tabular}{|c|c|c|c|c|c|}
\hline \multirow{3}{*}{$\begin{array}{l}\text { Which industry describes most closely } \\
\text { the industry you operate in? } \\
\text { Industry }\end{array}$} & \multirow{3}{*}{$\begin{array}{l}\text { Was your } \\
\text { assets..... } \\
\text {....higher } \\
\text { average } \\
\mathrm{N}\end{array}$} & \multirow{2}{*}{$\begin{array}{c}\text { company's } \\
\text { than }\end{array}$} & \multirow{3}{*}{$\begin{array}{l}\text { operatin } \\
\text { a...lower } \\
\text { average } \\
\mathrm{N}\end{array}$} & \multirow{3}{*}{$\begin{array}{l}\text { g profit/ret } \\
\text { than } \\
0\end{array}$} & \multirow{3}{*}{$\begin{array}{l}\text { urn or } \\
\text { Total }\end{array}$} \\
\hline & & & & & \\
\hline & & $\%$ & & & \\
\hline Other & 19 & 70.4 & 8 & 29.6 & 27 \\
\hline * Banks & 20 & 90.9 & 2 & 9.1 & 22 \\
\hline Household goods and house construction & 12 & 70.6 & 5 & 29.4 & 17 \\
\hline Health care & 40 & 58.0 & 29 & 42.0 & 69 \\
\hline Packaging & 11 & 73.3 & 4 & 26.7 & 15 \\
\hline Transport & 20 & 62.5 & 12 & 37.5 & 32 \\
\hline Business support services and training & 56 & 62.9 & 33 & 37.1 & 89 \\
\hline Beverages & 12 & 41.4 & 17 & 58.6 & 29 \\
\hline Electronics and electrical & 27 & 61.8 & 6 & 18.2 & 33 \\
\hline Information technology & 74 & 80.4 & 18 & 19.6 & 92 \\
\hline $\begin{array}{l}\text { Clothing, footwear, leisure \& personal } \\
\text { products }\end{array}$ & 8 & 42.1 & 11 & 57.9 & 19 \\
\hline Travel and leisure & 23 & 43.4 & 30 & 56.6 & 53 \\
\hline Building, construction and materials & 39 & 72.2 & 15 & 27.8 & 54 \\
\hline${ }^{*}$ Financial services & 50 & 80.6 & 12 & 19.4 & 62 \\
\hline Insurance & 10 & 43.5 & 13 & 56.5 & 23 \\
\hline Retail & 36 & 78.3 & 10 & 21.7 & 46 \\
\hline Automobiles. Parts and tyres & 20 & 55.6 & 16 & 44.4 & 36 \\
\hline Chemicals & 19 & 67.9 & 9 & 32.1 & 28 \\
\hline Food & 29 & 64.4 & 16 & 35.6 & 45 \\
\hline Media & 20 & 64.5 & 11 & 35.5 & 31 \\
\hline Telecommunications & 16 & 42.1 & 22 & 57.9 & 38 \\
\hline TOTAL & 561 & 65.2 & 299 & 34.8 & 860 \\
\hline
\end{tabular}

Discussion of research question assessment: In order to answer the research questions previously set, the industries were ranked from lowest to highest in terms of the combined complexity and turbulence index, as provided in Table 5. This ranking of industries is provided in Table 8. To test the findings the principle of 
maximal variation sampling was used (Patton, 1987), comparing the six highest (Top 6) versus the six lowest (Lowest 6) industries in terms of perceived level of complexity and turbulence as shown in Table 8.

Table 8: Ranking of industries in terms of complexity and turbulence

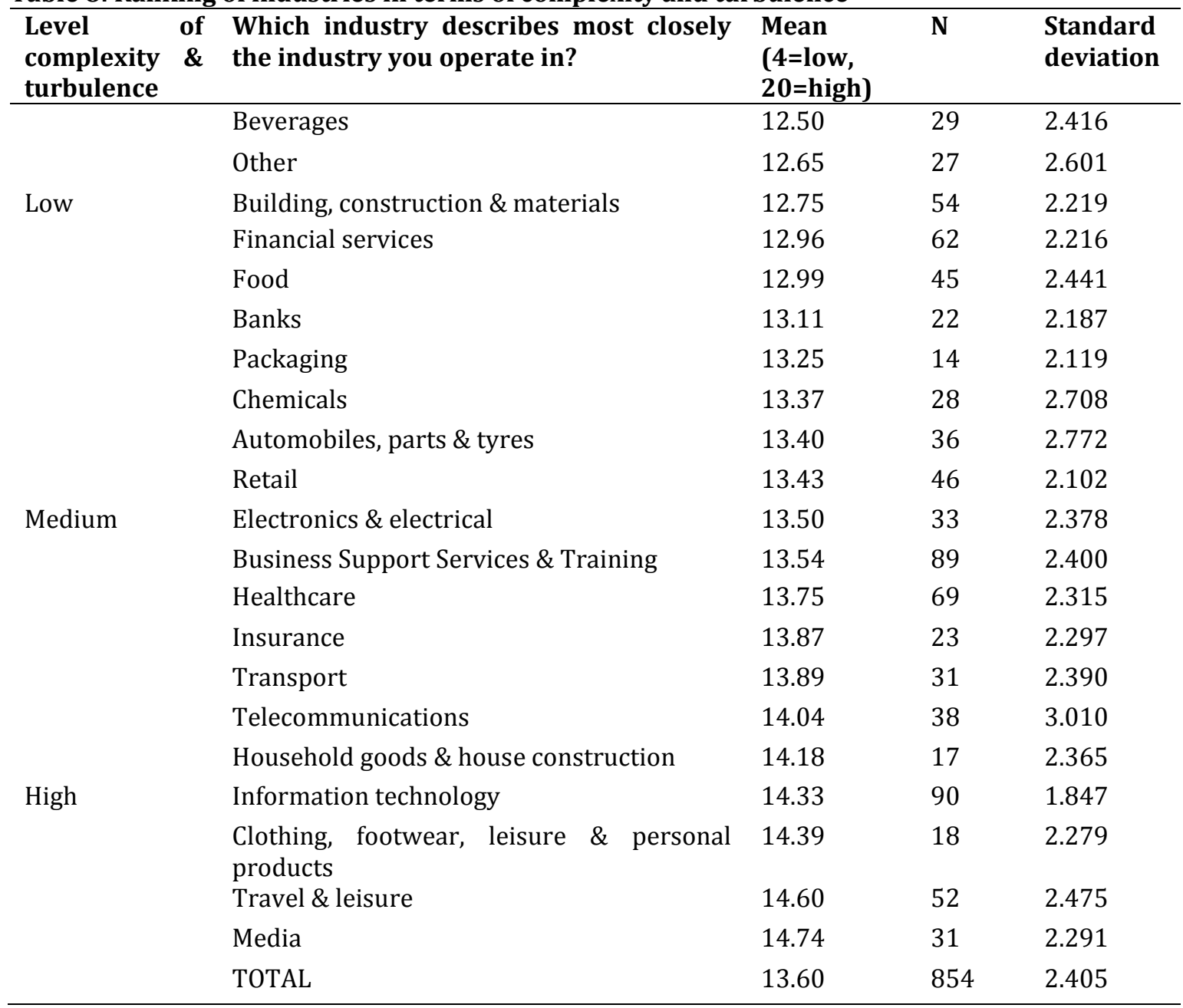

- $\quad R Q$ 1: Do companies in a more complex/turbulent environment feel that more destabilizing marketing tactics are more important? The Top 6 had a mean of $3.77(n=248$; SD $=.658)$ for the importance of destabilizing marketing instruments, whereas the Lowest 6 had a mean of $3.54(n=239$; $\mathrm{SD}=.676)$. This shows that the Top 6 do see destabilizing instruments as more important than the Lowest 6 do. This finding was significant with a $\mathrm{p}$ value of $0.000(\mathrm{t}=.3 .816$; $\mathrm{df}=485)$. Thus, the research question can be answered "yes"

- $\quad R Q$ 2: Do companies in a more simple/stable environment feel that more stabilizing marketing tactics are more important? The Lowest 6 had a mean of $4.01(\mathrm{n}=239$; SD $=.576)$ for the importance of stabilizing marketing instruments, whereas the Top 6 had a mean of $3.98(n=248 ; S D=.589)$. This shows that the Lowest 6 see stabilizing instruments as slightly more important than the Top 6 do. This finding, however, was not significant with a p value of $0.623(\mathrm{t}=-.492 ; \mathrm{df}=485)$. Thus, research question 2 cannot be answered with any level of confidence.

However, when comparing the Lowest 6's feelings about destabilizing instruments ( mean $=3.77 ; \mathrm{n}=248$; SD $=.658$ ) to their feelings about stabilizing instruments (mean $=3.98 ; \mathrm{n}=248 ; \mathrm{SD}=.589$ ), it can be seen that RQ 2 can be answered in the affirmative (significant with $\mathrm{p}=.000 ; \mathrm{df}=247$ ). To further assess the relationship, the type of marketing tactics was regressed against the nature of the perceived environment, producing Table 9. 
Table 9: Regression of nature of environment against marketing tactics

\begin{tabular}{llll}
\hline & $\mathbf{R}^{2}$ & Regress.Coef. & Sig \\
\hline $\begin{array}{l}\text { Complex/turbulent index regression to importance of } \\
\text { destabilising tactics Durban-Watson: 1,77; Tolerance: 0,99 }\end{array}$ & 0,29 & 0,17 & 0,000 \\
$\begin{array}{l}\text { Complex index regression to importance of destabilising tactics } \\
\text { Durban-Watson: 1,78; Tolerance: 0,99 }\end{array}$ & 0,24 & 0,154 & 0,000 \\
$\begin{array}{l}\text { Turbulent index regression to importance of destabilising tactics } \\
\text { Durban-Watson: 1,74; Tolerance: 0,99 }\end{array}$ & 0,23 & 0,152 & 0,000 \\
\hline
\end{tabular}

For all regressions, homoscedasticity was tested by a regression of the squared residuals on the independent variables and normal distribution of the residuals by a plot compared to the normal distribution. Both results are satisfying. Autocorrelation is tested by the Durban-Watson test and multicollinearity by the tolerance values (see both values in Table 9). This regression analyses show that, both with increasing complexity and turbulence, the importance of destabilizing tactics increases. Thus it can be concluded that destabilizing marketing instruments are very important in complex and turbulent environment.

The third objective of the study was to identify the relationship between the different marketing mix tactics and marketing success in complex/turbulent industries. To meet this objective, the more successful companies in highly complex/turbulent environments (as calculated from the original data used to construct Tables 7 and 8) were compared against all other companies. Those more successful in high complex/turbulent environments had a mean for importance of destabilising tactics of $3.74(\mathrm{n}=239$; $\mathrm{SD}=$ $.635)$, whereas the mean for all other companies was $3.60(\mathrm{n}=617 ; \mathrm{SD}=.681)$. This finding was significant at $\mathrm{p}=.004(\mathrm{t}=2.855 ; \mathrm{df}=854)$. Thus, it can be concluded that there is definitely a relation between the use of destabilising tactics and success in complex/turbulent environments. However, it was also found that less successful companies in complex/turbulent environments also saw destabilising activities as important $(\mathrm{p}=$ $.004 ; \mathrm{t}=2.876 ; \mathrm{df}=854$ ). As a further check, it was found that more successful and less successful firms in simple/stable environments do not have any significantly different attitudes to the use of stabilising marketing tactics.

Discussion of the Findings: These findings are now discussed in terms of the research objectives set for the study, namely:

Objective 1 -to test the model of the marketing mix tactics that could be expected to be found in successful companies in complex and turbulent environments,

The model of marketing mix tactics proposed in Table 1 has been shown by the findings to have some benefit for marketing managers. The results have highlighted that destabilising marketing tactics are important in complex/turbulent environments, and since most respondents from most industries saw their environments as more or less complex and turbulent (rather than simple and stable), such destabilising tactics would be important to all marketers. However, stabilising tactics should not be neglected, as they are also seen as having some importance - they help to avoid disruption of the firm's own relationships with loyal customers and build and maintain sound customer relationships and maintain customer loyalty (Mason, 2014).

Objective 2 -to identify the differences in marketing mix tactics between companies operating in complex/turbulent industries and in simple/stable industries,

There is a subtle difference in the attitudes towards the different marketing tactics between those companies in the more complex/turbulent environments and those in the less complex/turbulent environments. Although all firms indicate a belief in the importance of destabilising tactics, there is a difference in the intensity of these beliefs. Those in the more complex/turbulent environments feel destabilising tactics are more important than the stabilising tactics, whereas those in the less complex/turbulent environments feel that the stabilising tactics are more important than the destabilising tactics. What is not certain is the degree to which these differences are influenced by actual differences in environmental complexity/turbulence, as opposed to being influenced by the marketers' perceptions of such environmental complexity and turbulence. 
The fact that most respondents from most industries saw their environments as complex and turbulent to greater or lesser degrees, and very few saw them as simple and stable, highlights this weakness.

Objective 3 -to identify the relationship between the different marketing mix tactics and marketing success in complex/turbulent industries.

The findings showed a significant relationship between success and importance of destabilising tactics in more complex/turbulent environments. However, since even the less successful companies also indicated a belief in the importance of destabilising tactics, it cannot be concluded that there is a strong causative relationship. It could be, for example, that companies that perceive their environment as more complex and turbulent are more aggressive in the marketing activities as a result, and it could be the aggressiveness of the implementation of the tactics that leads to success. It is also possible that there is a relationship between short-term success and destabilising tactics, and a different relationship between long-term success and stabilising tactics, due to the relationship building nature of such tactics.

\section{Implications}

For marketers: Since the use of destabilising marketing tactics is clearly important in complex and turbulent environments, it is suggested that all marketers should make more use of destabilising tactics. Tactics such as: innovative and fast product development (involving customers in the process); innovative and aggressive pricing aimed at leading the market in pricing tactics; aggressive, shocking or amazing promotions campaigns intended to surprise and shift perceptions. However, such destabilising activities need to be tempered with some stability, especially with regard to maintaining strong customer relationships. For this reason, distribution is an important stabilizing force, but also helping to improve supply chain responsiveness and flexibility, which is consistent with the needs of complex, turbulent environments. Branding, corporate identity and personal selling are other tactics that can be used to maintain strong relationships whilst destabilising the rest of the market.

For academics: This study has confirmed some of the previous theoretical and exploratory studies that have emphasised the importance of using the new sciences (complexity and chaos theory) as techniques to better understand the market dynamics. It has shown that research in volatile markets would be less than optimal if they are not considered as complex adaptive systems and that, therefore, they are viewed through a complexity lens.

\section{Conclusion and Recommendations}

In terms of Objective 1, the study has shown that destabilising marketing tactics are important in complex/turbulent environments, but that stabilising tactics should also be used to stabilise the firm's own customer relationships. With regard to Objective 2, although all firms felt that the destabilising tactics are important, those in complex/turbulent environments felt that they were more important than stabilising tactics, while those firms in simple/stable environments felt that the stabilising tactics were more important. The results for Objective 3 showed a positive relationship between success and the perceived importance of destabilising tactics in complex/turbulent environments, but since even less successful firms saw destabilising tactics as important, this relationship cannot be concluded to be causative. The conclusion that can be reached from these analyses is that it is the evaluation of the environment that is more important. The more the environment is perceived to be complex and turbulent, the more important destabilising marketing tactics are seen to be. Furthermore, it can be concluded that the higher the complexity and turbulence, then the more important ALL marketing tactics become, which highlights the overall importance of marketing in the South African business environment.

Recommendations for further research: Because of the uncertainties highlighted by this study, it is recommended that further research be conducted, specifically:

- Research that investigates the actual implementation of stabilising and destabilising tactics, rather than just attitudes towards them 
- Investigation into whether there are differing relationships over the short-term versus the long-term with regard to the implementation of stabilising versus destabilising tactics.

- Identify an industry that is truly simple and stable, and accepted as such by its inhabitants, and

\section{References} investigate the use of stabilising versus destabilising tactics in that industry

Arévalo, L. E. B. \& Espinoza, A. (2014). Theoretical approaches to managing complexity in organizations: A comparative analysis. Estudios Gerenciales.

Ashill, N. J. \& Jobber, D. (2015).The effects of the external environment on marketing decision-maker uncertainty. Journal of Marketing Management, DOI: 10.1080/0267257X.2013.811281.

Badillo-Pina, I., Tejeida-Padilla, R. \& Morales-Matamoros, O. (2012). A systems science perspective for supply chain management. Proceedings of the 56th annual meeting of the ISSS, San Jose, CA, USA

Bar-Yam, Y. (2000). Guide to Complex Systems [online]. New England Complex Systems Institute. Available from: www.necsi.org/guide [Accessed 29 June 2000].

Black, J. \& Farias, G. (2000). Dynamic Strategies: Emergent Journeys. Emergence, 2(1), 101-113.

Briggs, J. \& Peat, F. D. (1999). Seven Life Lessons of Chaos: Timeless Wisdom from the Science of Change. New York: Harper Collins.

Burgess, S. M. \& Steenkamp, J. B. E. M. (2006). Marketing renaissance: How research in emerging markets advances marketing science and practice. International Journal of Research in Marketing, 23(4), 337356.

Chakravarthy, B. (1997).A New Strategy Framework for Coping with Turbulence. Sloan Management Review, $38(2), 69-82$.

Conner, D. R. (1998). Leading at the Edge of Chaos: How to Create the Nimble Organization. New York: Wiley.

D'Aveni, R. A. (1999). Strategic supremacy through disruption and dominance. Sloan Management Review, 40(3), 127-135.

Doherty, N. \& Delener, N. (2001). Chaos Theory: Marketing and Management Implications. Journal of Marketing Theory and Practice, 9(4), 66-75.

Dolan, S. L., Garcia, S. \& Auerbach, A. (2003). Understanding and Managing Chaos in Organizations. International Journal of Management, 20(1), 23-35.

Droge, C., Calantone, R. \& Harmancioglu, N. (2009). New product success: Is it really controllable by managers in highly turbulent environments? Journal of Product Innovation Management, 25(3), 272-286.

Edgar, D. A. \& Nisbet, L. (1996). A Matter of Chaos: some issues for hospitality businesses. International Journal of Contemporary Hospitality Management, 8(2), 6-9.

Fodness, D. (2015). Managing the wickedness of socially responsible marketing. Journal of Business Strategy, 36(5), 10-17.

Garcia, R. (2004). Encouraging Failure in New Product Development [online]. Paper presented at New Priorities and Challenges for Business-to-Business Marketers, 5 - 6 August, Harvard Business School, Boston. Available: www.smeal.psu.edu/isbm/seminars/boston04/Garcia.pdf [Accessed 17/9/2004]

Gladwell, M. (2000).The Tipping Point: How little things can make a big difference. London: Abacus.

Goldberg, J. \& Markoczy, L. (1998).Complex Rhetoric and Simple Games. Cranfield University. Available at: www.Cranfield.ac.za/public/cc/cc047/papers/ complex/html /complex.htm (accessed 2 February 1999).

Gundlach, G. T. (2006).Complexity science and antitrust. Antitrust Bulletin, 51(1), 17-31.

Heilbrunn, J. (1995). AMA Marketing Encyclopedia: Issues and Trends Shaping the Future. Chicago: American Marketing Association.

Hibbert, B. \& Wilkinson, I. F. (1994).Chaos Theory and the Dynamics of Marketing Systems. Journal of the Academy of Marketing Science, 22(3), 218-233.

Holbrook, M. B. (2003). Adventures in Complexity: Dynamic Open Complex Adaptive Systems, Butterfly Effects, Self-Organizing Order, Co-evolution, the Ecological Perspective, Fitness Landscapes, Market Spaces, Emergent Beauty at the Edge of Chaos, and All That Jazz. Academy of Marketing Science Review. Available at: www.amsreview.org/articles/holbrook06-2003.pdf (accessed 2 February 2006).

Kelly, S. \& Allison, M. A. (1999).The Complexity Advantage: How the Science of Complexity Can Help Your Business Achieve Peak Performance. New York: Business Week Books. 
Leitner, K. H. (2015). Pathways for the co-evolution of new product development and strategy formation processes: empirical evidence from major Austrian innovations. European Journal of Innovation Management, 18(2).

Lewin, R. (1992). Complexity: Life at the edge of chaos. New York: MacMillan.

Liu, H., Ma, L. \& Huang, P. (2015).When organizational complexity helps corporation improve its performance. Journal of Management Development, 34(3), 340-351.

Manuj, I. \& Sahin, F. (2011). A model of supply chain and supply chain decision-making complexity. International Journal of Physical Distribution \& Logistics Management, 41(5), 511-549.

Mason, R. B. (2004). An investigation into how marketers cope with an environment of high complexity and turbulence, with special reference to the South African environment. Unpublished PhD thesis, Rhodes University, Grahamstown, South Africa.

Mason, R. B. (2006). Coping with complexity and turbulence - an entrepreneurial solution. Journal of Enterprising Culture, 14(4), 241-266.

Mason, R. B. \& Staude, G. (2006).A marketing mix model for the complex and turbulent South African environment: A complexity theory approach. Paper read at the $1^{\text {st }}$ International Management Conference, University of Johannesburg, South Africa, 29-31 October.

Mason, R. B. \& Staude, G. (2007). A marketing mix model for a complex and turbulent environment: a complexity theory approach. Acta Commercii, 7, 236-254.

Mason, R. B. \& Staude, G. (2009). Marketing tactics in turbulent environments: A complexity theory approach. Industrial Management \& Data Systems, 109(2), 173-190.

Mason, R. B. (2007). The external environment's effect on management and strategy: A complexity theory approach. Management Decision, 45(1), 10-28.

Mason, R. B. (2008). Word of mouth as a promotional tool for turbulent markets. Journal of Marketing Communications, 14(3), 207-224.

Mason, R. B. (2012). Product tactics in a Complex and Turbulent Environment Viewed through a Complexity Lens. The Business Review, 21(1), 144-150.

Mason, R. B. (2013a). Distribution tactics in a turbulent environment: A complexity theory approach. Journal of Transport and Supply Chain management, 7(1), 1-9.

Mason, R. B. (2013b). Follow me, I'm right behind you: Complexity theory and leadership for turbulent environments. Journal of Social Sciences, 36(3), 295-307.

Mason, R. B. (2014). Marketing Communications and Environmental Turbulence: A Complexity Theory View. Journal of Economics and Behavioral Studies, 6(4), 279-290.

McCarthy, I. P., Tsinopoulos, C., Allen, P. M. \& Rose-Anderssen, C. (2006). New Product Development as a Complex Adaptive System of Decisions. Journal of Product Innovation Management, 23(5), 437-456.

McGlone, T. A. \& Ramsey, R. P. (1998).Getting Realistic about Reality: Using Chaos Theory to Explain Marketing Phenomena. Paper read at the Society for Marketing Advances conference, New Orleans, 4-7 November.

McGregor, B. F. A. (2012). McGregor BFA Research domain. Johannesburg. Available at http://research.mcgregorbfa.com/CompanySearchDefault.aspx?Token=7cAGVEWDwwuNlsMDFEKp $\mathrm{A} \% 3 \mathrm{~d} \% 3 \mathrm{~d} \&$ ClientID=1450\&ConModule=129\&ReturnURL=\%2fStation\%2fFinancialRatios $\% 2 \mathrm{fFinanc}$ ialRatiosDefault.aspx.(accessed 17 May 2012).

Meade, P. T. \& Rabelo, L. (2004).The technology adoption life cycle attractor: Understanding the dynamics of high-tech markets. Technological Forecasting and Social Change, 17, 667-684.

Melton, H. \& Hartline, M. D. (2015).Customer and employee co-creation of radical service innovation. Journal of Services Marketing, 29(2), 1-36

Mohr, J. (2001). Marketing of High-Technology Products and Innovations. Upper Saddle River: Prentice Hall.

Morrison, D. J. \& Quella, J. A. (1999).Pattern thinking: Cutting through the Chaos. Marketing Management, $8(4), 17-23$.

Nilson, T. H. (1995). Chaos Marketing: How to win in a turbulent world. London: McGraw-Hill.

Patton, M.Q. (1987). How to Use Qualitative Methods in Evaluation. Newbury Park: Sage.

Priyanker, P. V. \& Srinivasan, P. (2015).Marketing innovation to meet market complexity in the $21^{\text {st }}$ century. Global Journal of Commerce \& Management Perspective, 4(2), 12-15.

Richardson, B. (1996). Synthesis marketing: a shift of the marketing paradigm [online]. Professional Marketing, September. Available from: http://www.scenarioplanning.com/archive/art1.htm(accessed 24 February 1998). 
Ritter, T., Wilkinson, I. F. \& Johnston, W. J. (2004).Managing in complex business networks. Industrial Marketing Management, 33, 175-183.

Sekaran, U. \& Bougie, R. (2010). Research Methods for Business: A Skill Building Approach. (5th Ed.), Chichester: Wiley.

Seybold, P. B. (2000). Ubiquity Breeds Wealth. Business 2.0, supplement to Intelligence, May, 33-38.

Shalender, K. \& Singh, N. (2015). Marketing Flexibility: Significance and Implications for Automobile Industry. Global Journal of Flexible Systems Management, 4, 1-12.

Singer, J. (2006). Framing brand management for marketing ecosystems. Journal of Business Strategy, 27(5), 50-57.

Smith, A. (2002). Three Scenarios for Applying Chaos Theory in Consumer Research. Journal of Marketing Management, 18, 517-531.

Stacey, R. D. (1995). The science of complexity: An alternative perspective for strategic change processes. Strategic Management Journal, 16, 477-495.

Stacey, R. D. (1996). Complexity and Creativity in Organizations. San Francisco: Berrett-Koehler.

Tarokh, M. J., Dabiri, N., Shokouthi, A. H. \& Shafiei, H. (2011).The effect of supply network configuration on occurring chaotic behavior in the retailer's inventory. Journal of Industrial Engineering International, $7(14), 19-28$.

Tedesco, B. G. (1998). Neural Network Complexity Models for the Marketing Mix. Paper read at the Advertising Research Foundation Media Accountability Workshop, New York, October 1998.

Tedesco Analytics. (2001). Complexity Science and Consumer Decisions. Available at: http://www.TedescoAnalytics.com/content/philosophy/phil.htm (accessed 25 May 2001).

Theodoridis, C. (2009). Complexity in retail organizations: An empirically informed discussion with particular reference to retail location strategy. Available athttps://www.researchgate.net/ profile/Constantinos_Theodoridis/contributions (accessed 6 April 2015)

Turner, F. (2014).Quality, Quantity, Granularity, and Thresholds of Emergence. Cosmos + Taxis, 1(2), 1-7.

Vojtko, V. \& Heskova, M. (2010). Analyzing Retailing Opportunities and Threats Using Agent-Based Simulation. In Proceedings of the $14^{\text {th }}$ IBIMA Conference on Knowledge Management and Innovation in Advancing Economies, Istanbul, Turkey, International Business Information Management Association, 2514-2523.

Weeks, R. V. (2014). Management perspectives on dealing with contextual uncertainty and unexpected emergent events. Journal of Contemporary Management, 11, 703-722.

Wilden, R. \& Gudergan, S. P. (2015). The impact of dynamic capabilities on operational marketing and technological capabilities: investigating the role of environmental turbulence. Journal of the Academy of Marketing Science, 43, 181-199.

Wilkinson, I. F. (2006).The evolution of an evolutionary perspective of B2B business. Journal of Business and Industrial Marketing, 21(7), 458-465.

Wilkinson, I. \& Young, L. (1998).On Competing: Firms, Relations and Networks. Paper read at Research Conference on Relationship Marketing, October, Emory University.

Wilkinson, I. F. \& Young, L. C. (2013).The past and the future of business marketing theory. Industrial Marketing Management, 42, 394-404.

Wollin, D. \& Perry, C. (2004). Marketing management in a complex adaptive system: An initial framework. European Journal of Marketing, 38(5/6), 556-572.

Woodside, A. G. (2015). The general theory of behavioral pricing: applying complexity theory to explicate heterogeneity and achieve high-predictive validity. Industrial Marketing Management, available at http://dx.doi.org/10.1016/j.indarman.2015.02.004(accessed 16 March 2015).

Wu, Y. \& Zhang, D. Z. (2007). Demand fluctuation and chaotic behavior by interaction between customers and suppliers. International Journal of Production Economics, 107, 250-259. 